\title{
Chromohalobacter salarius sp. nov., a moderately halophilic bacterium isolated from a solar saltern in Cabo de Gata, Almería, southern Spain
}

Correspondence

Mercedes Monteoliva-Sánchez mmonteol@ugr.es

\author{
Margarita Aguilera, ${ }^{1}$ Antonio Cabrera, ${ }^{1}$ Claudia Incerti, ${ }^{1}$ Susana Fuentes, ${ }^{1}$ \\ Nick J. Russell, ${ }^{2}$ Alberto Ramos-Cormenzana ${ }^{1}$ \\ and Mercedes Monteoliva-Sánchez ${ }^{1}$
}
${ }^{1}$ Department of Microbiology, Faculty of Pharmacy, University of Granada, Campus Universitario de Cartuja s/n, 18071 Granada, Spain
${ }^{2}$ Microbiology Laboratories, Imperial College London, Wye Campus, Wye, Ashford, Kent TN25 $5 \mathrm{AH}, \mathrm{UK}$

\begin{abstract}
A moderately halophilic, Gram-negative bacterium (strain CG4. $1^{\top}$ ), which was isolated from a solar saltern at Cabo de Gata, a wildlife reserve located in the province of Almería, southern Spain, was subjected to a polyphasic taxonomic study. This organism was an aerobic, motile rod that produced colonies with a yellow pigment. Strain CG4.1 ${ }^{\top}$ grew at salinities of $3-25 \%(w / v)$, at $15-45^{\circ} \mathrm{C}$ and at $\mathrm{pH} 5-9$. The organism reduced nitrate, hydrolysed starch and had phenylalanine deaminase activity. The major fatty acids were $\mathrm{C}_{18: 1} \omega 7 c, \mathrm{C}_{16: 0}$ and $\mathrm{C}_{19: 0}$ cyclo $\omega 8 \mathrm{c}$. The DNA G +C content was $63.6 \mathrm{~mol} \%$. On the basis of phenotypic and phylogenetic data, strain CG4.1 $1^{\top}$ appears to be a member of the genus Chromohalobacter and clustered closely with Chromohalobacter species, with 95-96\% similarity between their 16S rRNA gene sequences. However, DNA-DNA relatedness between the isolate and the type strains of Chromohalobacter species was low. Therefore, it is proposed that strain CG4.1 ${ }^{\top}$ represents a novel species, Chromohalobacter salarius sp. nov. The type strain is strain CG4.1 ${ }^{\top}\left(=\mathrm{CECT} 5903^{\top}=\mathrm{LMG}\right.$ $23626^{\mathrm{T}}$ ).
\end{abstract}

Moderately halophilic micro-organisms represent a very heterogeneous group that are distributed extensively in high salinity zones (Rodríguez-Valera, 1988; Ventosa et al., 1998; Oren, 2002; Kaye et al., 2004). Among the bacterial families that form part of the Gammaproteobacteria, the family Halomonadaceae is characterized as being represented by several halophilic, halotolerant and non-halophilic species that belong to different genera. Members of the genus Chromohalobacter, which currently has seven species, form a monophyletic group included in the family Halomonadaceae (Arahal et al., 2002). Ventosa et al. (1989) reclassified 'Chromobacterium marismortui' as Chromohalobacter marismortui and other species were subsequently placed in the genus Chromohalobacter as follows: Chromohalobacter canadensis and Chromohalobacter israelensis (Arahal et al., 2001a), Chromohalobacter salexigens (Arahal et al., 2001b), Chromohalobacter sarecensis (Quillaguamán

The GenBank/EMBL/DDBJ accession number for the 16S rRNA sequence of strain CG4.1 $1^{\top}$ is AJ427626.

A phylogenetic tree based on the maximum-parsimony algorithm showing relationships between strain $\mathrm{CG} 4.1^{\top}$, Chromohalobacter species and other related taxa is available as supplementary material with the online version of this paper. et al., 2004), Chromohalobacter nigrandesensis (Prado et al., 2006), and Chromohalobacter beijerinckii (Peçonek et al., 2006). All these species are moderately halophilic, aerobic, motile, Gram-negative, heterotrophic rods.

In the screening of halophilic micro-organisms isolated from the solar saltern of Cabo de Gata, a wildlife reserve located in the province of Almería, southern Spain, a moderately halophilic Gram-negative bacterial organism, strain CG4.1 $1^{\mathrm{T}}$, was characterized by a polyphasic approach, including phylogenetic analysis based on 16S rRNA gene sequences, genomic relatedness and chemotaxonomic and phenotypic properties. The results reported in this study indicate that CG4. $1^{\mathrm{T}}$ belongs to the genus Chromohalobacter, but it is clearly distinguishable from all other Chromohalobacter species.

Water samples were spread on $\mathrm{MH}$ complex medium supplemented with a balanced mixture of sea salts to give an adequate salts concentration for growth of marine and moderately halophilic strains. This medium contained $\left(1^{-1}\right)$ $10 \mathrm{~g}$ yeast extract (Difco), $5 \mathrm{~g}$ proteose peptone no. 3 (Difco) and $1 \mathrm{~g}$ glucose (Ventosa et al., 1982) and it was supplemented with the balanced mixture of sea salts of Subov (1931). The $\mathrm{pH}$ was adjusted to 7.2 with $1 \mathrm{M} \mathrm{NaOH}$. 
The medium was solidified with $20 \mathrm{~g}$ Bacto agar (Difco) $\mathrm{l}^{-1}$. The isolate was maintained and routinely grown aerobically on $\mathrm{MH}$ complex medium with $7.5 \%(\mathrm{w} / \mathrm{v})$ total salts at $35^{\circ} \mathrm{C}$, except where indicated otherwise.

The methods used for phenotypic characterization have been described previously in detail (Ventosa et al., 1982; Quesada et al., 1983; Prado et al., 1991; Mata et al., 2002). The salts concentrations required for growth of strain CG4. $1^{\mathrm{T}}$ were determined at $35^{\circ} \mathrm{C}$. The strain was cultured in $\mathrm{MH}$ medium containing the following concentrations of a balanced mixture of sea salts (Subov, 1931): 0, 0.5, 3, 5, 7.5, $10,15,20,25$ and $30 \%(\mathrm{w} / \mathrm{v})$. Each $50 \mathrm{ml}$ medium batch was inoculated with $0.1 \mathrm{ml}$ (approximately $10^{5}$ cells per $\mathrm{ml}$ ) from an appropriate dilution of a $20 \mathrm{~h}$ culture of the microorganism grown in $\mathrm{MH}$ medium containing $7.5 \%(\mathrm{w} / \mathrm{v})$ salts. The cultures were incubated in a rotary shaker. Viable cells were determined from plate counts on solid $\mathrm{MH}$ medium at the appropriate salts concentration. Experiments were performed in triplicate. The $\mathrm{pH}$ growth range was determined in a similar way on $\mathrm{MH}$ medium by adjusting the final $\mathrm{pH}$ to values of $4,5,6,7,8,9$ and 10 with $\mathrm{HCl}$ or $\mathrm{NaOH}$. The temperature range was determined as above by incubating the strain at temperatures of $4,10,15,20,25,30$, $35,40,45$ and $50{ }^{\circ} \mathrm{C}$.

TEM and SEM were used for morphological studies of cells from a $20 \mathrm{~h}$ culture of strain CG4.1 ${ }^{\mathrm{T}}$ grown on the surface of $\mathrm{MH}$ agar plates covered with $\mathrm{MH}$ liquid medium $(7.5 \%$, $\mathrm{w} / \mathrm{v}$, salts). Cells for TEM were stained with $2 \%(\mathrm{w} / \mathrm{v})$ phosphotungstic acid and observed by using a Zeiss model EM 902 TEM. Samples for SEM were fixed in $2 \%(\mathrm{v} / \mathrm{v})$ glutaraldehyde solution ( $\mathrm{pH} 7.2$ ), dehydrated in an acetone series, critical-point-dried, coated with gold and scanned in a Zeiss model DSM950 SEM.

Whole-cell fatty acids of strain CG4.1 ${ }^{\mathrm{T}}$ were analysed by the Analytical Service Microbial Identification System (DSMZ, Braunschweig, Germany) using the MID/Hewlett Packard Microbial Identification System (MIS), which relies upon high-resolution GC to obtain the fatty acid profile. A moist pellet of cells obtained from cultivation on $\mathrm{MH}$ complex medium supplemented with $7.5 \%(\mathrm{w} / \mathrm{v})$ sea salts for 2 days at $35^{\circ} \mathrm{C}$ was used and the relative amount of each fatty acid was expressed as a percentage of the total fatty acids.

DNA was isolated and purified by the method of Lind \& Ursing (1986). The $\mathrm{G}+\mathrm{C}$ content $(\mathrm{mol} \%)$ was determined by the thermal denaturation method $\left(T_{\mathrm{m}}\right)$ (Marmur \& Doty, 1962) with a Perkin Elmer Lambda 3B spectrophotometer fitted with a temperature program accessory. DNA-DNA hybridization studies were performed using the nonradioactive method described by Ziemke et al. (1998). Reference DNA was double-labelled using DIG-11-dUTP and biotin-16-dUTP (Boehringer Mannheim). The labelling was carried out using the Boehringer Mannheim nicktranslation kit. Phylogenetic analysis based on the $16 \mathrm{~S}$ rRNA gene sequence of strain CG4.1 ${ }^{\mathrm{T}}$ was made as described previously (Prado et al., 2006). The sequence obtained was compared with other publicly available $16 \mathrm{~S}$ rRNA sequences deposited in the EMBL database. Sequences were aligned by using CLUSTAL W 1.8 (Thompson et al., 1994). Phylogenetic trees were constructed with the aid of the MEGA 3.1 software package (Kumar et al., 2004) using the neighbour-joining and maximum-parsimony algorithms.

Table 1 provides a comparison of the taxonomic features of strain CG4.1 $1^{\mathrm{T}}$ and Chromohalobacter species. Cells of strain CG4. $1^{\mathrm{T}}$ were Gram-negative straight rods, $2.5-3.2 \mu \mathrm{m}$ long and $1.2-1.3 \mu \mathrm{m}$ wide. They were motile by means of subpolar flagella. No spores were observed. Colonies of strain CG4. $1^{\mathrm{T}}$ on $\mathrm{MH}$ medium containing $7.5 \%(\mathrm{w} / \mathrm{v})$ salts were circular/slightly irregular, convex and yellow pigmented. Optimum growth of strain CG4.1 $1^{\mathrm{T}}$ was observed in 7.5$10.0 \%(\mathrm{w} / \mathrm{v})$ total salts in $\mathrm{MH}$ complex medium, and at $\mathrm{pH} 7.2$ and $35^{\circ} \mathrm{C}$. The isolate was able to grow at $35^{\circ} \mathrm{C}$ in $3-25 \%(\mathrm{w} / \mathrm{v})$ total salts; it was unable to grow in the absence of $\mathrm{NaCl}$. This result indicated that the isolate could be assigned to the group of moderately halophilic bacteria (Kushner \& Kamekura, 1988). With respect to its nutritional and biochemical characteristics, strain CG4. $1^{\mathrm{T}}$ showed some similarity to reference Chromohalobacter species, but differences were also noted. Strain CG4.1 ${ }^{\mathrm{T}}$ was able to hydrolyse starch and produce phenylalanine deaminase, activities that have not yet been described in Chromohalobacter species.

The major cellular fatty acids (up to $96 \%$ ) of strain CG4.1 ${ }^{\mathrm{T}}$ were $\mathrm{C}_{18: 1} \omega 7 c(43.0 \%), \mathrm{C}_{16: 0}(32.6 \%), \mathrm{C}_{19: 0}$ cyclo $\omega 8 c$ $(11.1 \%)$, and $\mathrm{C}_{16: 1} \omega 7 c$ and/or iso- $\mathrm{C}_{15: 0} 2-\mathrm{OH}(10.1 \%)$. The minor fatty acids of strain CG4. $1^{\mathrm{T}}$ were $\mathrm{C}_{17: 0}$ cyclo (1.7\%), $\mathrm{C}_{18: 1} \omega 7 c$ 11-methyl (0.5\%), $\mathrm{C}_{12: 0} 3$-OH (0.4\%), $\mathrm{C}_{18: 0}(0.3 \%), \mathrm{C}_{12: 0}(0.2 \%)$ and $\mathrm{C}_{14: 0}(0.2 \%)$. The variation in relative amounts in the fatty acid profile of strain CG4. $1^{\mathrm{T}}$ in relation to that reported for other Chromohalobacter species (Vargas et al., 2005; Mutnuri et al., 2005; Peçonek et al., 2006) can be explained by the different $\mathrm{NaCl}$ concentrations that were used in the growth media.

The DNA G + C content of strain CG4.1 ${ }^{\mathrm{T}}$ was $63.6 \mathrm{~mol} \%$. Strain CG4.1 ${ }^{\mathrm{T}}$ was placed within the genus Chromohalobacter based on its 16S rRNA gene sequence and shared $96.4 \%$ similarity with C. canadensis ATCC $43984^{\mathrm{T}}$, $95.9 \%$ similarity with C. marismortui ATCC $17056^{\mathrm{T}}$, $95.8 \%$ similarity with C. israelensis ATCC $43985^{\mathrm{T}}$, $95.6 \%$ similarity with C. salexigens DSM $3043^{\mathrm{T}}$, C. beijerinckii ATCC $19372^{\mathrm{T}}$ and C. sarecensis $\mathrm{LV}^{\mathrm{T}}$ and $95.5 \%$ similarity with C. nigrandesensis LST-4N ${ }^{\mathrm{T}}$. 16S rRNA gene sequence similarity between strain CG4.1 ${ }^{\mathrm{T}}$ and Halomonas desiderata $\mathrm{FB} 2^{\mathrm{T}}$ was $93 \%$, the highest value observed with species of the genus Halomonas. The phylogenetic tree constructed using the neighbour-joining algorithm showed that strain CG4.1 $1^{\mathrm{T}}$ exhibited closest phylogenetic affinity to the Chromohalobacter cluster (Fig. 1). The maximum-parsimony algorithm gave a similar result (see Supplementary Fig. S1 available in IJSEM Online).

DNA-DNA hybridization experiments between strain CG4. $1^{\mathrm{T}}$ and the type strains of previously described species 
Table 1. Differential characteristics of strain CG $4.1^{\top}$ and other Chromohalobacter species

Strains/species: 1, CG4.1 ${ }^{\mathrm{T}}$; 2, C. nigrandesensis; 3, C. marismortui; 4, C. canadensis; 5, C. israelensis; 6, C. salexigens; 7, C. sarecensis; 8, C. beijerinckii. Data from Ventosa et al. (1989), Arahal et al. (2001a, b, 2002), Quillaguamán et al. (2004), Peçonek et al. (2006), Prado et al. (2006) and this study. +, Positive; -, negative; NR, not reported.

\begin{tabular}{|c|c|c|c|c|c|c|c|c|}
\hline Characteristic & 1 & 2 & 3 & 4 & 5 & 6 & 7 & 8 \\
\hline \multicolumn{9}{|l|}{ Ranges for growth } \\
\hline $\mathrm{NaCl}(\%, \mathrm{w} / \mathrm{v})$ & $3-25$ & $0.5-25.0$ & $2-30$ & $3-25$ & $3.5-20.0$ & $0.9-25.0$ & $0-25$ & $0.3-25.0$ \\
\hline $\mathrm{pH}$ & $5-9$ & $5-10$ & $5-10$ & $5-9$ & $5-9$ & $5-9$ & $5-10$ & $4.5-8.0$ \\
\hline Temperature $\left({ }^{\circ} \mathrm{C}\right)$ & $15-45$ & $15-45$ & $5-45$ & $15-45$ & $15-45$ & $4-45$ & $0-45$ & $4-42$ \\
\hline Flagellar arrangement & Subpolar & Subpolar & Peritrichous & Polar & Polar & Subpolar & Polar & Polar \\
\hline Pigmentation & Yellow & Black & Brown-yellow & White & Cream & White-cream & Brown & Yellow \\
\hline Oxidase & - & - & + & - & - & - & + & + \\
\hline Phenylalanine deaminase & + & - & - & - & - & - & NR & NR \\
\hline Phosphatase & + & - & - & + & - & $\mathrm{NR}$ & NR & - \\
\hline \multicolumn{9}{|l|}{ Acid production from: } \\
\hline Arabinose & - & + & - & + & + & + & - & + \\
\hline Maltose & - & - & + & - & + & + & - & - \\
\hline Sucrose & - & + & + & - & + & + & - & - \\
\hline Nitrate reduction & + & - & - & + & + & + & - & + \\
\hline Indole production & - & - & - & + & + & - & - & - \\
\hline $\mathrm{H}_{2} \mathrm{~S}$ production & + & + & - & - & - & + & - & + \\
\hline \multicolumn{9}{|l|}{ Hydrolysis of: } \\
\hline Aesculin & - & - & - & + & + & - & - & - \\
\hline Starch & + & - & - & - & - & - & - & - \\
\hline \multicolumn{9}{|l|}{ Growth on: } \\
\hline Cellobiose & - & - & - & + & + & - & + & NR \\
\hline Citrate (Simmons') & + & + & + & - & - & + & NR & + \\
\hline DNA G $+\mathrm{C}$ content $(\mathrm{mol} \%)$ & 63.6 & 59.9 & $62-65$ & 62 & 65 & $62.4-66.0$ & 56.1 & $60.4-60.7$ \\
\hline
\end{tabular}

of Chromohalobacter showed DNA-DNA relatedness values below $25 \%$ with C. marismortui ATCC $17056^{\mathrm{T}}$, C. canadensis CECT $5385^{\mathrm{T}}$, C. israelensis CECT $5287^{\mathrm{T}}$, C. salexigens CECT $5384^{\mathrm{T}}$, C. sarecensis CCUG $47987^{\mathrm{T}}$, C. nigrandesensis CECT $5315^{\mathrm{T}}$ and C. beijerinckii ATCC $19372^{\mathrm{T}}$.

On the basis of morphological, phenotypic and genotypic data, it is proposed that strain CG4. $1^{\mathrm{T}}$ should be classified as a representative of a novel species within the genus Chromohalobacter, Chromohalobacter salarius sp. nov.

\section{Description of Chromohalobacter salarius} sp. nov.

Chromohalobacter salarius (sa.la'ri.us. L. masc. adj. salarius of or belonging to salt, because this micro-organism was isolated from brine samples).

Cells are Gram-negative straight rods, 2.5-3.2 × 1.2-1.3 $\mu \mathrm{m}$, appearing either singly or in pairs. They are motile by one subpolar flagellum and do not form endospores. Colonies are yellow, circular/slightly irregular and convex. Moderately halophilic, growing in a wide range $(3-25 \%, w / v)$ of salts concentrations (mixture of sea salts) with optimum growth at $7.5-10.0 \%(\mathrm{w} / \mathrm{v})$ salts; no growth occurs in the absence of salt. Grows at $15-45^{\circ} \mathrm{C}$ (optimal temperature $35^{\circ} \mathrm{C}$ ) and $\mathrm{pH} 5-9$ (optimal $\mathrm{pH} 7.0$ ). Catalase is produced but not oxidase. Chemo-organotrophic. Starch and Tween 20 are hydrolysed. Does not hydrolyse aesculin, gelatin, casein, tyrosine, Tween 80 or urea. Produces phosphatase and phenylalanine deaminase. $\mathrm{H}_{2} \mathrm{~S}$ is produced from L-cysteine. Positive for nitrate and nitrite reduction. Negative for indole, methyl red, Voges-Proskauer and haemolysis. Acids are produced from D-galactose and Dglucose, but not from L-arabinose, D-adonitol, D-cellobiose, glycerol, myo-inositol, lactose, maltose, D-mannitol, Dmannose, D-melezitose, L-raffinose, L-rhamnose, D-salicin, D-sorbitol, sucrose, D-trehalose or D-xylose. Acetate, citrate, formate, fumarate, gluconate, lactate, malate, malonate, propionate, pyruvate, succinate, D-mannitol, D-fructose, D-glucose, lactose and D-mannose are used as sole carbon and energy sources, whereas adonitol, myo-inositol, sorbitol, D-cellobiose, D-galactose, maltose, L-rhamnose, sucrose and D-xylose are not. L-Arginine, L-lysine, L-ornithine and L-serine are used as sole carbon, nitrogen and energy sources, whereas L-alanine, L-histidine, DL-isoleucine and L-valine are not. Susceptible to amoxicillin $(25 \mu \mathrm{g})$, ampicillin $(10 \mu \mathrm{g})$, cefoxitin $(30 \mu \mathrm{g})$, chloramphenicol $(30 \mu \mathrm{g})$, nalidixic acid $(30 \mu \mathrm{g})$, penicillin $\mathrm{G}(10 \mathrm{U})$, polymyxin $\mathrm{B}$ (300 IU) and rifampicin $(30 \mu \mathrm{g})$. Resistant to erythromycin $(15 \mu \mathrm{g})$, streptomycin $(10 \mu \mathrm{g})$ and tetracycline $(30 \mu \mathrm{g})$. The major fatty acids (up to $96 \%$ ) are $\mathrm{C}_{18: 1} \omega 7 c, \mathrm{C}_{16: 0}, \mathrm{C}_{19: 0}$ cyclo $\omega 8 c$ and $\mathrm{C}_{16: 1} \omega 7 c$ and/or iso- $\mathrm{C}_{15: 0} 2-\mathrm{OH}$. 


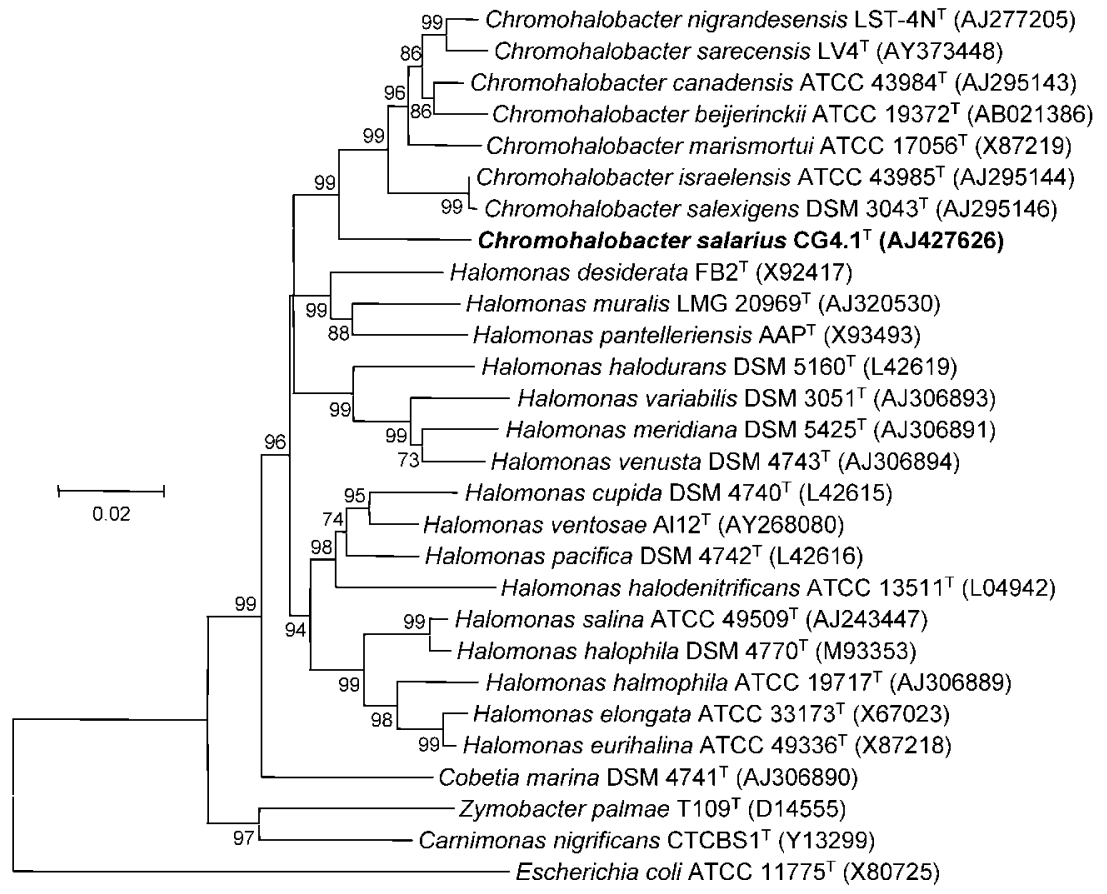

Fig. 1. Phylogenetic relationship between strain $\mathrm{CG} 4.1^{\top}$ and all species of the genus Chromohalobacter, several species of the genus Halomonas and the related species Zymobacter palmae, Cobetia marina and Carnimonas nigrificans. The tree was constructed using the neighbour-joining algorithm based on 16S rRNA gene sequences. GenBank accession numbers of the sequences used in the phylogenetic analysis are given in parentheses. Escherichia coli ATCC $11775^{\top}$ was used as the outgroup. Only bootstrap values greater than $50 \%$ are shown (1000 replications). Bar, 0.02 substitutions per nucleotide position.
The type strain is CG4.1 $1^{\mathrm{T}}\left(=\mathrm{CECT} 5903^{\mathrm{T}}=\mathrm{LMG} 23626^{\mathrm{T}}\right.$ ), isolated from a solar saltern in Cabo de Gata (Almería, Spain). The DNA G+C content of the type strain is $63.6 \mathrm{~mol} \%$ ( $T_{\mathrm{m}}$ method).

\section{Acknowledgements}

We are grateful to Dr Jean Euzéby for etymological advice. This study was supported by grants from the Plan Andaluz de Investigación, Spain (research group CVI 190).

\section{References}

Arahal, D. R., García, M. T., Ludwig, W., Schleifer, K. H. \& Ventosa, A. (2001a). Transfer of Halomonas canadensis and Halomonas israelensis to the genus Chromohalobacter as Chromohalobacter canadensis comb. nov. and Chromohalobacter israelensis comb. nov. Int J Syst Evol Microbiol 51, 1443-1448.

Arahal, D. R., Garcia, M. T., Vargas, C., Cánovas, D., Nieto, J. J. \& Ventosa, A. (2001b). Chromohalobacter salexigens sp. nov., a moderately halophilic species that includes Halomonas elongata DSM 3043 and ATCC 33174. Int J Syst Evol Microbiol 51, 1457-1462.

Arahal, D. R., Ludwig, W., Schleifer, K. H. \& Ventosa, A. (2002). Phylogeny of the family Halomonadaceae based on $23 \mathrm{~S}$ and $16 \mathrm{~S}$ rDNA sequence analyses. Int J Syst Evol Microbiol 52, 241-249.

Kaye, J. Z., Márquez, M. C., Ventosa, A. \& Baross, J. A. (2004). Halomonas neptunia sp. nov., Halomonas sulfidaeris sp. nov., Halomonas axialensis sp. nov. and Halomonas hydrothermalis sp. nov.: halophilic bacteria isolated from deep-sea hydrothermal-vent environments. Int J Syst Evol Microbiol 54, 499-511.

Kumar, S., Tamura, K. \& Nei, M. (2004). MEGA3: integrated software for molecular evolutionary genetics analysis and sequence alignment. Brief Bioinform 5, 150-163.
Kushner, D. J. \& Kamekura, M. (1988). Physiology of halophilic eubacteria. In Halophilic Bacteria, vol. I, pp. 109-140. Edited by F. Rodríguez-Valera. Boca Raton, FL: CRC Press.

Lind, E. \& Ursing, J. (1986). Clinical strains of Enterobacter agglomerans (synonyms: Erwinia herbicola, Erwinia milletiae) identified by DNA-DNA-hybridization. Acta Pathol Microbiol Immunol Scand Sect B 94, 205-213.

Marmur, J. \& Doty, P. (1962). Determination of the base composition of deoxyribonucleic acid from its thermal denaturation temperature. J Mol Biol 4, 109-118.

Mata, J. A., Martínez-Cánovas, J., Quesada, E. \& Bejar, V. (2002). A detailed phenotypic characterisation of the type strains of Halomonas species. Syst Appl Microbiol 25, 360-375.

Mutnuri, S., Vasudevan, N., Kastner, M. \& Heipieper, H. J. (2005). Changes in fatty acid composition of Chromohalobacter israelensis with varying salt concentrations. Curr Microbiol 50, 151-154.

Oren, A. (2002). Diversity of halophilic microorganisms: environments, phylogeny, physiology, and applications. I Ind Microbiol Biotechnol 28, 56-63.

Peçonek, J., Gruber, C., Gallego, V., Ventosa, A., Busse, H.-J., Kämpfer, P., Radax, C. \& Stan-Lotter, H. (2006). Reclassification of Pseudomonas beijerinckii Hof 1935 as Chromohalobacter beijerinckii comb. nov., and emended description of the species. Int J Syst Evol Microbiol 56, 1953-1957.

Prado, B., Del Moral, A., Quesada, E., Ríos, R., Monteoliva-Sanchez, M., Campos, V. \& Ramos-Cormenzana, A. (1991). Numerical taxonomy of moderately halophilic Gram negative rods isolated from the Salar of Atacama, Chile. Syst Appl Microbiol 14, 275-281.

Prado, B., Lizama, C., Aguilera, M., Ramos-Cormenzana, A., Fuentes, S., Campos, V. \& Monteoliva-Sánchez, M. (2006). Chromohalobacter nigrandesensis sp. nov., a moderately halophilic, Gram-negative bacterium isolated from Lake Tebenquiche on the Atacama Saltern, Chile. Int J Syst Evol Microbiol 56, 647-651.

Quesada, E., Ventosa, A., Rodríguez-Valera, F., Megías, L. \& Ramos-Cormenzana, A. (1983). Numerical taxonomy of moderately 
halophilic Gram-negative bacteria from hypersaline soils. J Gen Microbiol 129, 2649-2657.

Quillaguamán, J., Delgado, O., Mattiasson, B. \& Hatti-Kaul, R. (2004). Chromohalobacter sarecensis sp. nov., a psychrotolerant moderate halophile isolated from the saline Andean region of Bolivia. Int J Syst Evol Microbiol 54, 1921-1926.

Rodríguez-Valera, F. (1988). Characteristics and microbial ecology of hypersaline environments. In Halophilic Bacteria, vol. I, pp. 3-30. Edited by F. Rodríguez-Valera. Boca Raton, FL: CRC Press.

Subov, N. N. (1931). Oceanographical Tables. Moscow: USSR Oceanographic Institute Hydrometeorological Commission.

Thompson, J. D., Higgins, D. G. \& Gibson, T. J. (1994). CLUSTAL W: improving the sensitivity of progressive multiple sequence alignment through sequence weighting, position-specific gap penalties and weight matrix choice. Nucleic Acids Res 22, 4673-4680.

Vargas, C., Kallimanis, A., Koukkou, A. I., Calderon, M., Canovas, D., Iglesias-Guerra, F., Drainas, C., Ventosa, A. \& Nieto, J. J. (2005).
Contribution of chemical changes in membrane lipids to the osmoadaptation of the halophilic bacterium Chromohalobacter salexigens. Syst Appl Microbiol 28, 571-581.

Ventosa, A., Quesada, E., Rodriguez-Valera, F., Ruiz-Berraquero, F. \& Ramos-Cormenzana, A. (1982). Numerical taxonomy of moderately halophilic Gram-negative rods. J Gen Microbiol 128, 1959-1968.

Ventosa, A., Gutierrez, M. C., Garcia, M. T. \& Ruiz-Berraquero, F. (1989). Classification of 'Chromobacterium marismortui' in a new genus, Chromohalobacter gen. nov., as Chromohalobacter marismortui comb. nov., nom. rev. Int J Syst Bacteriol 39, 382-386.

Ventosa, A., Nieto, J. J. \& Oren, A. (1998). Biology of moderately halophilic aerobic bacteria. Microbiol Mol Biol Rev 62, 504-544.

Ziemke, F., Höfle, M. G., Lalucat, J. \& Rosselló-Mora, R. (1998). Reclassification of Shewanella putrefaciens Owen's genomic group II as Shewanella baltica sp. nov. Int J Syst Bacteriol 48, 179-186. 